\title{
An insight into the economics of groundwater exploitation - southeast Nigeria
}

\author{
*Igonor E.E. ${ }^{1}$, Oko, A. A $^{2}$ and Oden, M.I. ${ }^{2}$ \\ ${ }^{1}$ Department of Geology, University of Ibadan, Ibadan; eeigonor@yahoo.com: \\ ${ }^{2}$ Department of Geology, University of Calabar, Calabar, Nigeria.
}

\begin{abstract}
The rate of unemployment in the world is rising and the probability of getting a job is on a steady decline since economies are not able to generate sufficient employment opportunities to absorb growth in the working-age population. Since it is evident that global economies are failing and would be so for some time, what is needed now for a global solution are entrepreneurs. On this background, geoscientist are called upon to look at the marketability of groundwater exploration and exploitation for commercial purpose in the face of the gross global unemployment crisis, as a means of not only surviving the harsh times, but also helping mankind to satisfy and quench their thirst. Groundwater borehole drilling is a viable venture for a geoscientist as the profitability is high.
\end{abstract}

Keywords: business, economic geology, entrepreneur, groundwater, Oban and Obudu massif.

\section{Introduction}

Of all the natural resources, groundwater is one that touches all aspect of human life and affects the society in great ways. Research shows that $95 \%$ of the earth unseen fresh water are found among voids in soils and permeable geologic formations as groundwater and over half the world population depend on its proper exploitation for existence (1).

According to the Global Trends Report, 2011, the rate of unemployment in the world is rising and the probability of getting a job is on a steady decline since economies are not able to generate sufficient employment opportunities to absorb growth in the working-age population. Data from 64 countries show that as at the $2^{\text {nd }}$ quarter of 2010, the number of countries with falling employment-to-population ratio was still twice the number of countries with rising ratios. There is little hope for this figure to revert to earlier comfort level (2). And the geosciences sector is not exempted from this global crisis. Like many other professional groups, the global geosciences work force faces two major concerns (3): the pending retirement of professional; and the uncertainty regarding the adequacy of this replacement with respect to quality and quantity. And according to updates from the IUGS taskforce on the global geosciences workforce, (3), these concerns are not limited to developing countries but also acute in developed nations.

Since it is evident that the government and the few private industries cannot provide sufficient job for the teeming geosciences workforce, it is obvious that what are needed now for a global solution are entrepreneurs (4).

On this background of the marketability of groundwater and the gross global unemployment crisis, it is the opinion of the authors that adequate knowledge and proper exploitation of groundwater is a viable venture for a geoscientist.

This paper aims at empowering graduate geoscientists with basic but necessary entrepreneurial skills in the area of borehole drilling with emphasis on the economics of the trade and the southeast of Nigeria as a case study bearing in mind that Economic Geology is defined properly as "the study of how the geosciences industry organises its money from trading geological materials in the business world" or still as "the study of how money influences (demand and supply) of geological materials within the geosciences business world" (4). 


\section{The geology of the southeast of Nigeria}
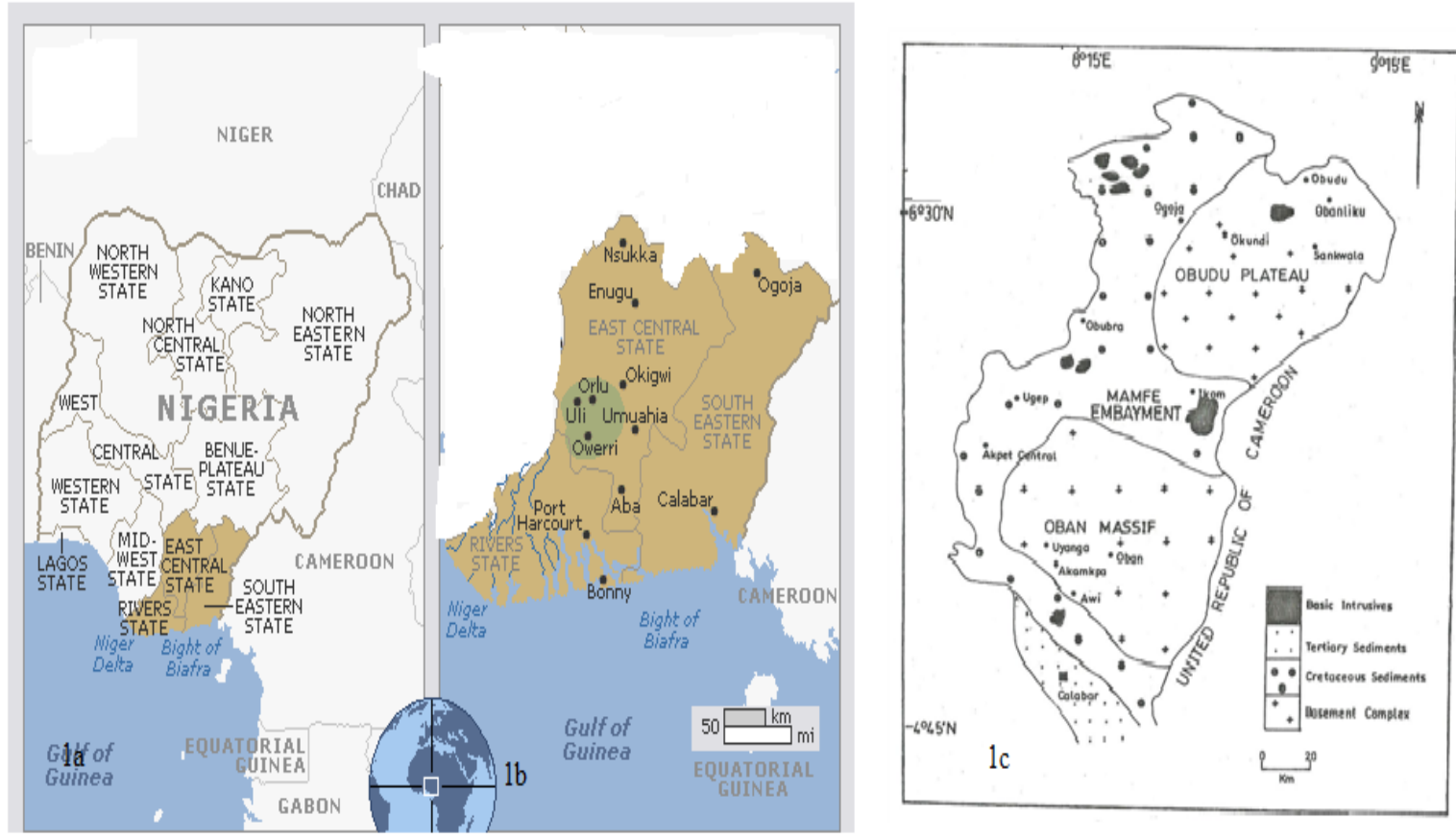

Figure 1 showing the topographic map of Nigeria (a), southeast Nigeria (b) and the geologic map of some parts of the southeast of Nigeria (c) with emphasis on the basement complex areas (Microsofte Encarta@ 2009)

The sedimentary cover of southeast Nigeria: South-eastern Nigeria has a geology that is dominated by Cretaceous-Tertiary sedimentary cover of the lower Benue Trough, which in all comprises of the Calabar Flank, the Mamfe Embayment, the Anambra Basin, Afikpo syncline, Abakaliki Anticlinotiourm and the Niger Delta, which lie uncomformably on rocks of the crystalline basement (Oban-Obudu massif) which are Precambrian in age $(5,6,7,8,9,10$ among others.) (see Fig. 1)

Due to early exploration and exploitation of some economic minerals like lead-zinc, coal and petroleum, present and hosted by the sedimentary rocks in this area (southeast of Nigeria), the nature and characteristics of the sedimentary cover of the region is well known. According to (8), the sedimentary basins of the lower Benue Trough are among the coastal basins of Central West Africa and are believed to be vestiges of fragmentation and dispersal of Gondwanaland.

The Abakaliki Anticlinorium, which was formed during the Santonian, is occupied mainly by the shales of the Asu River Group; the Anambra Basin is mainly filled by Upper Cretaceaous and Tertiary sediments (11) with occasional occurrences of shales, coquina lenses and immature feldsapthic sandstones (12); while marine sediments of Albian to Maestritchian age sometimes reaching $1000 \mathrm{~m}$ in thickness, basal fluviodeltic sands also known as the Awi formation, Mfamosing limestone, black to dark gray shales, and intercalations of marls and impure limestones characterise the Calabar Flank $(13 ; 14 ; 15 ; 8)$.

The basement complex of SE Nigeria: The extensive Precambrian rocks of Nigeria better known as the Basement Complex, covers about $50 \%$ of Nigeria and extends into the neighbouring countries, Benin and Cameroun (16). In the southeast of Nigeria, the Oban and Obudu massifs are the only two occurrences of the Precambrian rocks. These massifs have been affected by metamorphic events, tectonism, magmatism and metasomatism which also affected the geology of other areas of Nigeria crystalline basement. This is based on the observed rock types and their lithotectonic patterns $(17,18 ; 19 ; 20$ and 21). Consequently, the Oban massif has been identified to be made up of three main lithologic units viz: (1) Migmatitic and sheared gneissic rocks, schists, phyllites, meta-conglomerates and quartzites, amphibolites and meladiorites, deformed pegmatites and aplites, and pyroxenite - which forms the basement rocks as in other Basement Complex area of the country; (2) Older Granite intrusive series comprising meladiorites, granodiorites, adamellites to granitic rocks; pegmatites, aplite and quartz veins - which intrudes the first unit of rocks above; (3) Unmetamorphosed dolerite to microdioritic intrusives. Pegmatites, which occur ubiquitously in the area of study are either external or internal vein structures, and occur in high angle structures (22). Detailed description of these rocks have been described by (19); (24); and (21) among others. 


\section{Discussion}

Groundwater is a hidden natural resource whose occurrence and distribution is greatly dependent on both the local and regional geology, and also the hydrogeologic setting. For this reason, before any business venture of exploiting this resource, a geologic exploration is necessary to determine the general geology of the proposed site. As a general guide, most of the drilling exercises in the southeast of Nigeria would be in a sedimentary terrain, except for areas within the oban and Obudu massifs where basement rocks may be encountered.

Exploration for groundwater: Utmost exploitation of groundwater requires rapid and cost effective techniques of locating its water bearing units (aquiferous zones). And since groundwater is characterized by certain parameters, geophysical methods are used to determine from surface measurements, the presence of groundwater in an area. Application of geophysical methods for groundwater exploration is based on the fact that certain physical properties of rocks change considerably with water content in them (25). These changes (in physical properties) constitute a physical boundary which is characterized by variation in density, conductivity and elastic properties.

Groundwater occurrence in a Precambrian Basement terrain is hosted within zones of weathering and fracturing which often are not continuous in vertical and lateral extent (26). But in sedimentary areas, groundwater occurs in basins or 'inverted cones'. To avoid drilling abortive wells, geophysical investigation is imperative because it helps to delineate potential water bearing geological unit(s).

Exploitation of groundwater: Major cities in the southeast of Nigeria are getting densely populated and the population is still on the rise because of recent development in the states. The progressive population growth has led to severe shortage of portable drinking water for the area which poses as a great challenge to both the citizens and the government. Similarly, there is a steady rise in the demand for groundwater in most hard rock areas most of which cannot boast of any constant surface source of water supply (26). Ironically, this bleak picture throws up business opportunities for groundwater exploration and borehole drilling to satisfy the market.

\section{The economics of borehole drilling}

It is the authors' belief that the reader is conversant with the general basics of business running and contract sourcing, so only the drilling aspect of the business would be discussed here.

Borehole drilling for groundwater in the southeast of Nigeria (and in fact other parts of the world) thrives most in the dry season when rain fall is almost nil and is most profitable.

Experts in the field have confirmed that the drilling contract comes in various packages depending on the interest of the client viz:

(a) The punch and case package: this involves only the drilling and casing of the borehole. The client decides how and when to install all other facilities to make the bored hole functional;

(b) The complete package: this involves drilling and casing of the hole and also the installation of a pumping machine (submersible or surface);

(c) and lastly the comprehensive or 'overall' package: this package takes care of the drilling, casing, installation of a pumping machine, and an overhead tank, plus the necessary plumbing works. As the name entails, the comprehensive package is the ultimate deal.

\section{Costings}

As the packages are different, so are the contract costs. Rough estimates of the various contract costs are:

a) Punch and case package - \#250,000 - \#350,000

b) Complete package - \#400,000 - \#500,000

c) Comprehensive package - \#1,200,000 - \#1,400,000

Factors that affect the cost of the packages: the cost of the packages vary based on

I. The terrain of operation - basement complex areas are more difficult to operate in and hence more expensive.

II. The depth of drilling - though there could be a certain average depth to be drilled with the certainty of getting good groundwater, some clients prefer the hole going further than the average depth. This attracts more cost.

III. The clients involved - it is an open secret that the contract cost of drilling varies upward when the client involve is any arm of the government.

IV. The type of drilling equipment used - since the cost of acquiring manual drilling equipments is far lesser than that of the advanced drilling type, that is, the rotary drilling machine (figure 2a), it is expected that the cost of drilling manually would be much lesser than when using the rotary drilling machine. 


\section{Ventures in the borehole drilling business}

The borehole drilling business has various ventures for all those who would be interested depending on the available start up capital. Three basic options are open to would be entrepreneurs, and these are:

(a) The initial exploration stage, which involves the use of geophysical instrument to search for and locate suitable site to drill for groundwater. In this case the start up capital is small since the instrument for exploration could either be bought (a new terameter goes for about \#4.5 million, depending on the model and the capacity) or hired for about \#40,000 - \#50,000 per day;

(b) Involvement in the direct drilling and maintenance of groundwater well. In this case one could buy his/her drilling rig, compressor and other equipments needed (a new rig (figure 2) goes for between \#15 - \#35 million, while a locally constructed one is about \#3million. A fairly used compressor goes for about \#4.5million) or, considering the high cost of purchasing these equipments, hire them at reasonable fees per day;

(c) Another low cost opportunity for low or no capital entrepreneurs is in the sub-contracting of a won groundwater drilling contract. In this case, an entrepreneur bids for and wins the groundwater drilling contract, and because of lack of funds to execute the project, it is subcontracted to a more capable firm, at a fee a little less than the overall project sum. For start-ups, this is the most likely profitable route to follow.

\section{Profitability profile of groundwater drilling project}

Considering the many variables involved in the drilling project; like the various type of project packages; the various factors affecting the package cost; and the different level of operation of the business, the profitability profile would be too clumsy and variable to put down. Nevertheless, an entrepreneur can be rest assured that at least about $30 \%-40 \%$ of the total project cost could be made as profit from any particular drilling venture.

\section{Conclusion}

Groundwater is of major importance to civilization, because it is the largest reserve of drinkable water in regions where humans can live and is often preferable because it tends to be less contaminated by wastes and organisms. The usefulness of this natural resource and its seeming scarcity to all at all times, since it is found underground, has opened up a very viable business opportunity that will definitely remain with us for a long time to come.

No doubt the groundwater borehole drilling venture is a profitable one; one still needs a sound knowledge and understanding of the geology of the area, exploration geophysics, and some mathematical skills to succeed as an expert in the field.

\section{Acknowledgement}

The authors wish to thank Mr. Emmanuel Arikibe, for his practical contribution.

\section{References}

[1]. Oteri, A. U., "Groundwater Resources of Nigeria," Waterfront, 2003, 19-22.

[2]. Kapos, S. And Sparreboom, T. Global employment Trends 2011 - the challenge of a jobs recovery. Int. Labour Office (ILO), Geneva. 2011, 107

[3]. Keane, C. And Gonzales, L. 2011. A global view of the geosciences profession: updates from the IUGS taskforce on the Global Geosciences Workforce. Geophysical Research abstracts. EGU general assembly. EGU 2011 - 1799. Vol. 13

[4]. Igonor, E.E and Oden, M.I.. Empowering geoscientists with entrepreneurial skills-bring back the 'economics' in economic geology course. Journ. Sci. and Multidisciplinary Research. Vol.2. 2010, 76-81.

[5]. Reyment, R.A. 1965. Aspects of the geology of Nigeria. Ibadan Univ. Press, Ibadan. Nigeria.

[6]. Cratchley, C.R. and Jones, J.P. An interpretation of the geology and gravity anomalies of the Benue valley, Nigeria. Overseas Geol. Surv. Geophysics. 1965, Paper 1:1-26.

[7]. Murat, R.C., Stratigraphy and Palaeogeography of Creataceous and lower Tertiary in southern Nigeria. In: T.F.J. Dessauvagie and A.J. whiteman (eds), African Geology. Ibadan univ. Press, Ibadan, Nigeria, 1972, p.251-269.

[8]. Petters, S.W. Central West African Cretaceous - Tertiary benthic Foraminifera and stratigraphy. Palaeontographica, Abt. A, 179, 1982:1 - 104.

[9]. Whiteman, A. 1982. Nigeria: its petroleum geology, resources and potential. Graham and Trotman, London.

[10]. Ekwueme, B.N., Nyong, E.E. and Petters, S.W. Geological Excursion Guidebook to Oban Massif, Calabar Flank and Mamfe Embayment, southeastern Nigeria. Dec-ford Publishers Ltd., Calabar, Nigeria. 1995, 36pp.

[11]. Benkhelil, J. Cretaceous deformation, magmatism and metamorphism in the Lower Benue Trough, Nigeria. Geol. J., 22; 1987, $467-493$.

[12]. Amajor, L.C. The Cenomanian hiatus in the Southern Benue Trough, Nigeria. Geol. Mag., $122(1) ; 1985,39$ - 50.

[13]. Nyong, E.E. and Ramanthan, R.M. A record of Oxygen-deficient Palaeo-environments in the Cretaceous of the Calabar Flank, S.E. Nigeria. J. Afr. Earth Sci., 3(4); 1985, $455-460$.

[14]. Adeleye, D.R. and Fayose, F.A. Stratigraphy of the type section of Awi Formation, Odukpani area, southeastern Nigeria. J. Min. Geol., 15; 1978, 33 - 37.

[15]. Foster, R.. Evidence of an open Seaway between northern and southern proto-Atlantic in Albian times. Nature, 272; 1978, 158159. 
[16]. Oyawoye, M.O. On an occurrence of fayalite quartz monzonite in the basement complex around Bauchi, northern Nigeria. Geol. Mag., XCVIII (6): 1964, 450-482.

[17]. Rahman, A.M.S., Ukpong, E.E. and Azmatullah, M., Geology of parts of the Oban massif, southeastern Nigeria. Journ. Min. Geol., vol. 18,(11), 1981, 60-65.

[18]. Rahman, A.M.S., Ekwere, S.J., Azmatullah, M. And Ukpong, E.E. Petrology and geochemistry of granitic intrusive rocks from the western part of Oban massif, southeastern Nigeria. Journ. African Earth Science, vol.7, 1988, 149-159.

[19]. Ekwueme, B.N. and Schlag, C. Compositions of monazites in pegmatites and related rocks of Oban massif, southeast Nigeria: implications for economic mineral exploration. IGCP No.255 Newsletter/bulletin, 2, 1989, 15-20.

[20]. Ekwueme, B.N., On the occurrence of crystalline (basement complex) rocks in SW Ugep, Nigeria. Jour. Min. geol. Vol.26(1), 1990d, 69-74.

[21]. Igonor, E.E., Oden, M.I., and Ukwang, E.E. Geochemical evaluation of basement rocks within Igbofia-uyanga-Iwuru area, SE Nigeria. 46th Annu. Conf. Nig. Min. Geosci. Soc., Calabar, Nigeria, abstract, 2010, pp.9

[22]. Oden, M.I. The pegmatite veins of western Oban massif: tectonic and lithological controls on physical properties. 46th annu. Conf. Nig. Min. Geosci. Soc., Calabar, Nigeria, Abstract, 2010, pp. 7

[23]. Nganje, T.N., and Ekwueme, B.N., Occurrence, petrography and structure of Uwet-granodiorite, southeastern Nigeria. Global Journ. Pure and Applied sci., vol.2(2), 1996, 213-228.

[24]. Davis, S. N., and DeWest, R., 1966, Hydrogeology, J. Willy and Sons, New York, Inc.

[25]. Jeff D. (2006) "Forum for groundwater" htt://www.waternet.co.za/groundwater/(3) December 2006. York, Inc.

[26]. Microsoft $®$ Encarta $₫,(2009)$. $\odot$ Microsoft Corporation, USA. 